\title{
Effects of the Antiandrogen Flutamide on the Expression of Protein Kinase C Isoenzymes in LNCaP and PC3 Human Prostate Cancer Cells
}

\author{
Leire Montalvo, ${ }^{1}$ María J. Carmena, ${ }^{1}$ Oscar Bolaños, ${ }^{1}$ Nieves Rodríguez-Henche, ${ }^{1}$ \\ Manuel Sánchez-Chapado, ${ }^{2}$ and Juan C. Prieto ${ }^{1,3}$
}

Flutamide is a nonsteroidal antiandrogen that is frequently used for total androgen blockage in the treatment of advanced prostate cancer. We investigated the effect of this antiandrogen on the expression of protein kinase $\mathrm{C}$ (PKC) isoenzymes $(\alpha, \beta 1, \varepsilon, \zeta)$ that are involved in cell growth, apoptosis and neoplastic transformation. Androgen-dependent (LNCaP) and independent (PC3) human prostate cancer cells were cultured in a medium that contained fetal bovine serum (FBS) or charcoal-stripped serum (CSS) and treated with $10 \mu \mathrm{M}$ flutamide. The expression of PKC isoenzymes and the androgen receptor (AR) were analyzed by Western blot and RT-PCR, respectively. Serum steroids differentially regulate the expression of PKC isoenzymes in LNCaP and PC3 cells. Flutamide up-regulated the expression of $\alpha, \beta 1$ and $\zeta$, but not $\varepsilon, \mathrm{PKC}$ isoenzymes in CSS-LNCaP cells. These results were not homogeneously reproduced in the presence of androgens. We observed an opposite effect of flutamide, compared to CSS, on PKC $\beta 1$ isoform expression in CSS-LNCaP suggesting that this antiandrogen exerts an agonistic effect. In PC3 cells flutamide potentiated the expression of the four PKC isoenzymes in almost all conditions tested (FBS- and CSScultured cells). Such effect of flutamide in PC3 cells is independent of AR since no expression of AR was detected. These results provide new evidence on antagonistic/agonistic responses of prostate cancer cells to antiandrogen drugs that are widely used in therapy and show that flutamide can elicit responses in prostate cancer cells that do not express AR.

KEY WORDS: Protein kinase C isoenzymes, antiandrogen, flutamide, androgen receptor, prostate cancer.

\section{INTRODUCTION}

Protein kinase $\mathrm{C}(\mathrm{PKC})$ isoenzymes regulate important cellular processes such as proliferation, differentiation, apoptosis and neoplastic transformation [1, 2]. The isoenzymes have defined cellular functions and are arranged into three groups: conventional PKCs $(\alpha, \beta 1, \beta 2, \gamma)$, which are $\mathrm{Ca}^{2+}$-dependent and activated by

\footnotetext{
${ }^{1}$ Departamento de Bioquímica y Biología Molecular, Universidad de Alcalá, E-28871 Alcalá de Henares, Spain.

${ }^{2}$ Servicio de Urología, Hospital Príncipe de Asturias, y Departamento de Cirugía, Universidad de Alcalá, E-28871 Alcalá de Henares, Spain.

${ }^{3}$ To whom all correspondence should be addressed. Departamento de Bioquímica y Biología Molecular, Universidad de Alcalá, E-28871 Alcalá de Henares, Spain. Fax: 34-91-8854585; E-mail: juancarlos.prieto@uah.es
} 
diacylglycerol (DAG) or phorbol esters and phosphatidylserine (PS); novel PKCs ( $\delta$, $\varepsilon, \eta, \theta)$, which are $\mathrm{Ca}^{2+}$-independent but are activated by DAG and PS; and atypical PKCs $(\zeta, z, \lambda)$, which are $\mathrm{Ca}^{2+}$ - and DAG-independent but are PS sensitive $[3,4]$.

Prostate cancer is a leading cause of cancer death among men in Western countries. There is an emerging understanding of the role played by PKC isoenzymes in the regulation of prostate cancer cell growth and programmed death which may provide novel therapeutic targets during the progression of the disease [5-8]. Advanced prostate cancer is commonly treated by surgical or chemical castration in combination with antiandrogens. This results in androgen ablation that suppresses cell proliferation and activates apoptosis in androgen-dependent cells [9]. The primary role of androgens on the proliferation and functionality of prostate cells [10] provides the rationale for this therapy. Unfortunately, the treatment is only palliative since prostate cancer progresses despite antiandrogen administration because of the emergence of androgen-independent cells [11]. This is a gradual transition accompanied by a complex array of molecular events including mutation of androgen receptors (AR), gene amplification, co-regulators and signal transduction cross-talk $[12,13]$. Interestingly, AR mutations may result in a shift in the behavior of AR ligands, i.e., from antagonist to agonist properties, as has been suggested for flutamide. In this regard, treatment with this nonsteroidal antiandrogen elicited paradoxical agonistic responses in both human prostate cancer tissue with AR gene mutations [14, 15] and in androgen-dependent LNCaP cells [16]. The AR mutation in LNCaP consists of a single nucleotide substitution, resulting in one amino acid change in the ligand-binding domain of the receptor (T877A) [17]. As a consequence of this mutation, the AR is activated in response to unusual ligands such as estrogens and progestagens, as well as antiandrogens $[17,18]$. Flutamide has also been reported to behave as a weak partial agonist of the wild type AR [15]. We have previously shown that treatment of rats with flutamide blocks adenylate cyclase activation through G-protein coupled receptors in prostate cell membranes [19], a pattern that is also evoked by PKC activation in rat prostate cells [20]. Moreover, we have recently observed that flutamide upregulates the expression of different $\mathrm{PKC}$ isoenzymes in both normal and castrated rat prostates [21]. In the present report, we address the study of the regulation of the expression of four $(\alpha, \beta 1, \varepsilon, \zeta)$ PKC isoforms in prostate cancer cells by flutamide and by androgen availability. To this aim, we used androgen-dependent (LNCaP) and androgen-insensitive (PC3) human prostate cancer cells that were cultured with flutamide in a medium containing either fetal bovine serum (FBS) or charcoal-stripped serum (CSS).

\section{MATERIALS AND METHODS}

\section{Cells and Reagents}

The human prostate cancer cell lines LNCaP and PC3 were purchased from the American Type Culture Collection (Rockville, MD, USA). Rabbit polyclonal antibodies against PKC isoenzymes (anti- $\alpha$ : sc-208; anti- $\beta \mathrm{I}$ : sc-209; anti- $\zeta$ : sc-216 and anti- $\varepsilon$ : sc-214) were purchased from Santa Cruz Biotechnology (Santa Cruz, CA, USA). The anti-rabbit IgG horseradish peroxidase conjugate was from 
Calbiochem-Novabiochem (San Diego, CA, USA). The peroxidase system Supersignal kit for Western blotting was from Pierce (Rockford, IL, USA). Media, sera, and penicillin/streptomycin for cell culture were from Gibco (Barcelona, Spain); oligonucleotides for PCR and chemiluminescence film were from Amersham Pharmacia Biotech (San Cugat, Spain). Molecular-weight markers and protein electrophoresis reagents were from Bio-Rad (Hercules, CA, USA). The Ultraspec kit for RNA extraction was from Biotecx (Houston, TX, USA) and the Ecotaq polymerase from Ecogen (Barcelona, Spain). Flutamide and other reagents were from Sigma (Alcobendas, Spain).

\section{Cell Culture and Cellular Fractionation}

LNCaP and PC3 cells were maintained in RPMI-1640 supplemented with 10\% FBS, 100 units penicillin and $0.1 \mathrm{mg} / \mathrm{ml}$ streptomycin and passaged weekly. Some experiments in both cell lines involved keeping the cells in $10 \%$ CSS to remove steroids. CSS was obtained by treatment of FBS with charcoal/Dextran T70 (10:1, $\mathrm{w} / \mathrm{w}$ ) followed by low-speed centrifugation [22]. Before antiandrogen treatment, cells were grown for 3 days in medium supplemented with $10 \%$ FBS or CSS. Thereafter, the cells were treated for $24 \mathrm{~h}$ with $10 \mu \mathrm{M}$ flutamide, washed twice with cold phosphate buffered saline (PBS) and scraped in $1 \mathrm{ml}$ cold homogenization buffer consisting of $20 \mathrm{mM}$ Tris- $\mathrm{HCl}(\mathrm{pH} 7.5)$ supplemented with $5 \mathrm{mM}$ EDTA, $5 \mathrm{mM}$ EGTA, $12.8 \mathrm{mM} \quad \beta$-mercaptoethanol, $10 \mathrm{mM}$ benzamidine, $0.3 \mathrm{mM}$ phenylmethylsulfonilfluoride (PMSF), $25 \mu \mathrm{g} / \mathrm{ml}$ leupeptine and $0.01 \%$ serum trypsin inhibitor (STI). The homogenate was kept at $-80^{\circ} \mathrm{C}$ for $30 \mathrm{~min}$ to lyse the cells. Protein concentration was determined [23], using bovine serum albumin as a standard.

\section{Western Blot Analysis of PKC Isoenzymes}

Sample aliquots with equivalent amounts of protein $(15 \mu \mathrm{g})$ were boiled, fractionated in $8 \%$ SDS-PAGE, and transferred onto a $0.45 \mu \mathrm{m}$ nitrocellulose membrane. After transfer, the membranes were blocked for $2 \mathrm{~h}$ at room temperature with a solution of $5 \%(\mathrm{w} / \mathrm{v})$ fat-free milk in $20 \mathrm{mM}$ Tris $(\mathrm{pH} 7.4) / 137 \mathrm{mM} \mathrm{NaCl}$, containing $0.1 \%(\mathrm{v} / \mathrm{v})$ Tween-20 (TBST). Incubation with the primary antibodies (antiPKC $\alpha, \beta 1, \varepsilon, \zeta)$ was performed for $90 \mathrm{~min}$ at $4^{\circ} \mathrm{C}$, followed by three washes with TBST containing $5 \%$ fat-free milk and incubation with the secondary antibody for $1 \mathrm{~h}$ at $4^{\circ} \mathrm{C}$. Immunoreactive bands were detected by enhanced chemiluminescence using the Supersignal kit (Pierce) according to the manufacturer's directions. Bands were quantified by densitometric scanning using Scion Image software (Scion Corporation, MD, USA). Controls for the immunochemical studies were carried out by replacing the primary antibodies by TBST and incubating with the secondary antibody according to the above protocol.

\section{RNA Isolation and AR RT-PCR}

Total cell RNA was isolated using the Ultraspec kit. Two $\mu \mathrm{g}$ of RNA was reverse transcribed by the Moloney murine leukemia virus reverse transcriptase 
(Gibco) at $37^{\circ} \mathrm{C}$ for $60 \mathrm{~min}$ in a $20 \mu \mathrm{l}$ mixture with hexamer random primers (Gibco). PCR was performed with human specific AR primers. The nucleotide bases were 5'-TCACACATTGAAGGCTATGA-3' for the upstream primer, and 5'-GTGGAAATAGATGGGCTTGA-3' for the downstream primer [24]. A $2.5 \mu 1$ volume of the reverse-transcribed mixture was subjected to PCR in a $25 \mu \mathrm{l}$ mixture consisting of $10 \mathrm{mM}$ Tris- $\mathrm{HCl}(\mathrm{pH} 8.3), 50 \mathrm{mM} \mathrm{KCl}, 3 \mathrm{mM} \mathrm{MgCl} 2,1 \mathrm{mM}$ of each $\mathrm{dNTP}, 0.5$ units of EcoTaq polymerase, and $0.5 \mathrm{pmol}$ of the primers. Thirty-five cycles of reaction at 94,55 and $72^{\circ} \mathrm{C}$ for 30,60 and $60 \mathrm{~s}$, respectively, were carried out in a PTC-100 Programmable Thermal Controller (MJ Research, Inc., Waltham, MA, USA). Amplified cDNA was subjected to electrophoresis in a $1.2 \%$ agarose gel containing $100 \mathrm{ng} / \mathrm{ml}$ ethidium bromide. After electrophoresis, gels were viewed and photographed under UV light illumination.

\section{Statistical Analysis}

The results are expressed either as the mean \pm SEM or as representative experiments. When appropriate, statistical significance was assessed by ANOVA and the Student's $t$ test. The level of significance was regarded at $p<0.05$.

\section{RESULTS}

Western blot analysis with specific antisera allowed us to detect the four PKC isoenzymes studied $(\alpha, \beta 1, \varepsilon, \zeta)$ in both androgen-dependent (LNCaP) and androgeninsensitive (PC3) human prostate cancer cells. This was true either in the presence or absence of androgens (i.e., culturing the cells with FBS or CSS, respectively) (Fig. 1). The observation of a second, faint band in some cases could be associated to different states of protein phosphorylation. It should be noted that PKC activity is achieved by both subcellular localization and phosphorylation, and Western-blots performed in the present study were carried out in whole cell lysates. There were different patterns of band intensity in the Western-blots of the PKC isoenzymes depending on the androgen dependence of the cell line: band intensity in control conditions (FBS) was similar in both cell lines for the $\beta 1$ and $\zeta$ isoenzymes whereas the $\alpha$ and $\varepsilon$ isoenzymes exhibited higher density values in PC3 cells as compared with LNCaP cells. We analyzed the effect of CSS (compared to FBS) on the level of expression of PKC isoenzymes in both cell lines. Densitometric quantitation of Western blot analysis of $\alpha, \beta 1, \varepsilon$ and $\zeta$ PKC isoforms in $\mathrm{LNCaP}$ and PC3 cells is shown in Fig. 1. In CSS-cultured LNCaP cells, we observed differential regulation of the expression of $\mathrm{PKC}$ isoenzymes: increased expression of $\mathrm{PKC} \alpha$ and $\mathrm{PKC} \zeta$, no significant change in $\mathrm{PKC} \varepsilon$ expression, and decreased expression of $\mathrm{PKC} \beta 1$. On the other hand, in CSS-cultured PC3 cells we observed a very significant up-regulation of $\mathrm{PKC} \varepsilon$ expression and similar increases in the expression of $\mathrm{PKC} \alpha$ and $\zeta$, whereas no significant changes for PKC $\beta 1$ expression were found.

We have previously observed that flutamide increases the expression of ventral prostate PKC isoenzymes $(\alpha, \beta, \zeta$ and $\varepsilon)$ from both control and castrated rats [21]. In this study we analyzed the effect of flutamide on the level of expression of these four PKC isoenzymes in LNCaP and PC3 human prostate cancer cells. Densitometric quantitation of Western blot analysis of $\alpha, \beta 1, \varepsilon$ and $\zeta \mathrm{PKC}$ isoforms in 

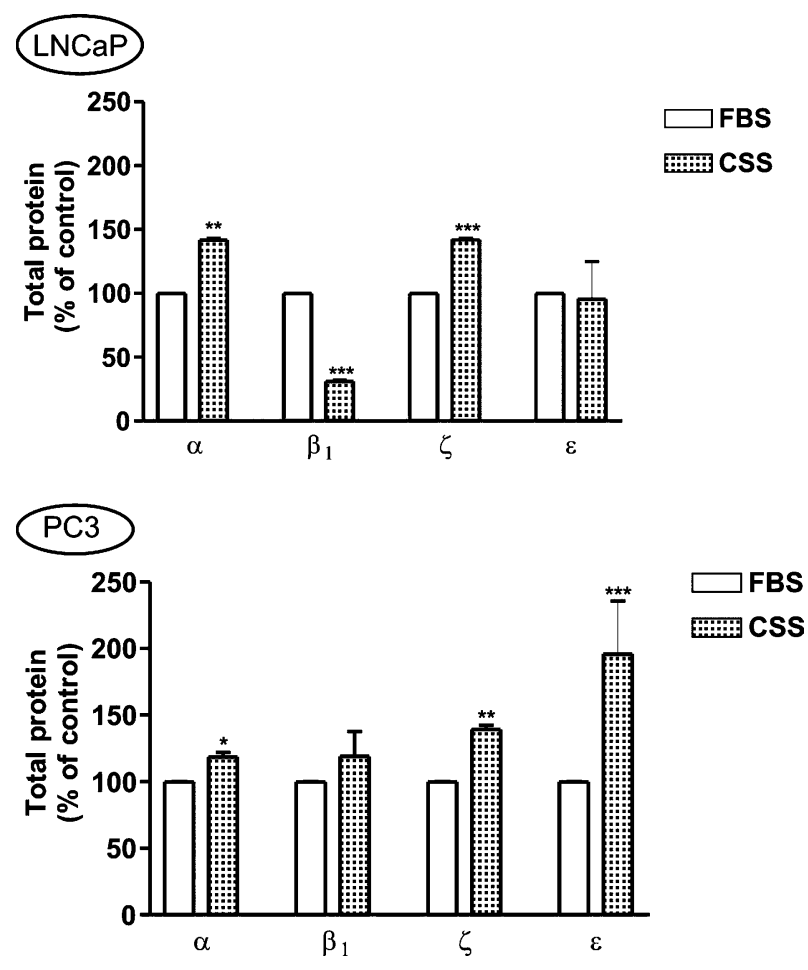

Fig. 1. Regulation of the expression of PKC isoenzymes in LNCaP and PC3 human prostate cancer cells by serum steroid availability. Cells were grown for 4 days in medium supplemented with $10 \%$ FBS or CSS. Whole cell lysates were separated by SDS-PAGE and immunoblotting was performed with PKC isoenzyme-specific antibodies $(\alpha, \beta 1, \varepsilon, \zeta)$ as indicated (see Methods). The intensities of the bands were quantified by densitometry scanning and normalized by representing them as a percentage of the control (FBS). The bars represent means \pm SEM of four experiments. $* p<0.05$, $* * p<0.01$ compared to control.

LNCaP and PC3 cells is shown in Figs. 2 and 3. In order to analyze the effect of flutamide, we normalized the data by representing them as a percentage of their respective controls (FBS or CSS). In the absence of androgens (i.e., with CSS) it can be seen that flutamide consistently increased, in a statistically significant manner, the expression of the four PKC isoenzymes in both cell lines (with the exception of $\mathrm{PKC} \varepsilon$ in $\mathrm{LNCaP}$ cells and $\mathrm{PKC} \zeta$ in PC3 cells). However, some heterogeneity was observed when androgens were present (i.e. with FBS): in LNCaP cells, flutamide did not modify $\mathrm{PKC} \alpha, \zeta$ or $\varepsilon$ expression and inhibited $\mathrm{PKC} \beta 1$ expression; in PC3 cells, the antiandrogen increased the expression of three PKC isoenzymes $(\beta 1, \beta$ and $\varepsilon)$ and did not exert any effect on PKC $\alpha$ expression. These results are summarized in Table 1, where densitometric data are expressed as a percentage of control 1 (FBS).

Surprisingly, flutamide up-regulates the expression of the four PKC isoenzymes studied in PC3 cells (Fig. 3). Since this cell line does not express the AR, which is the 

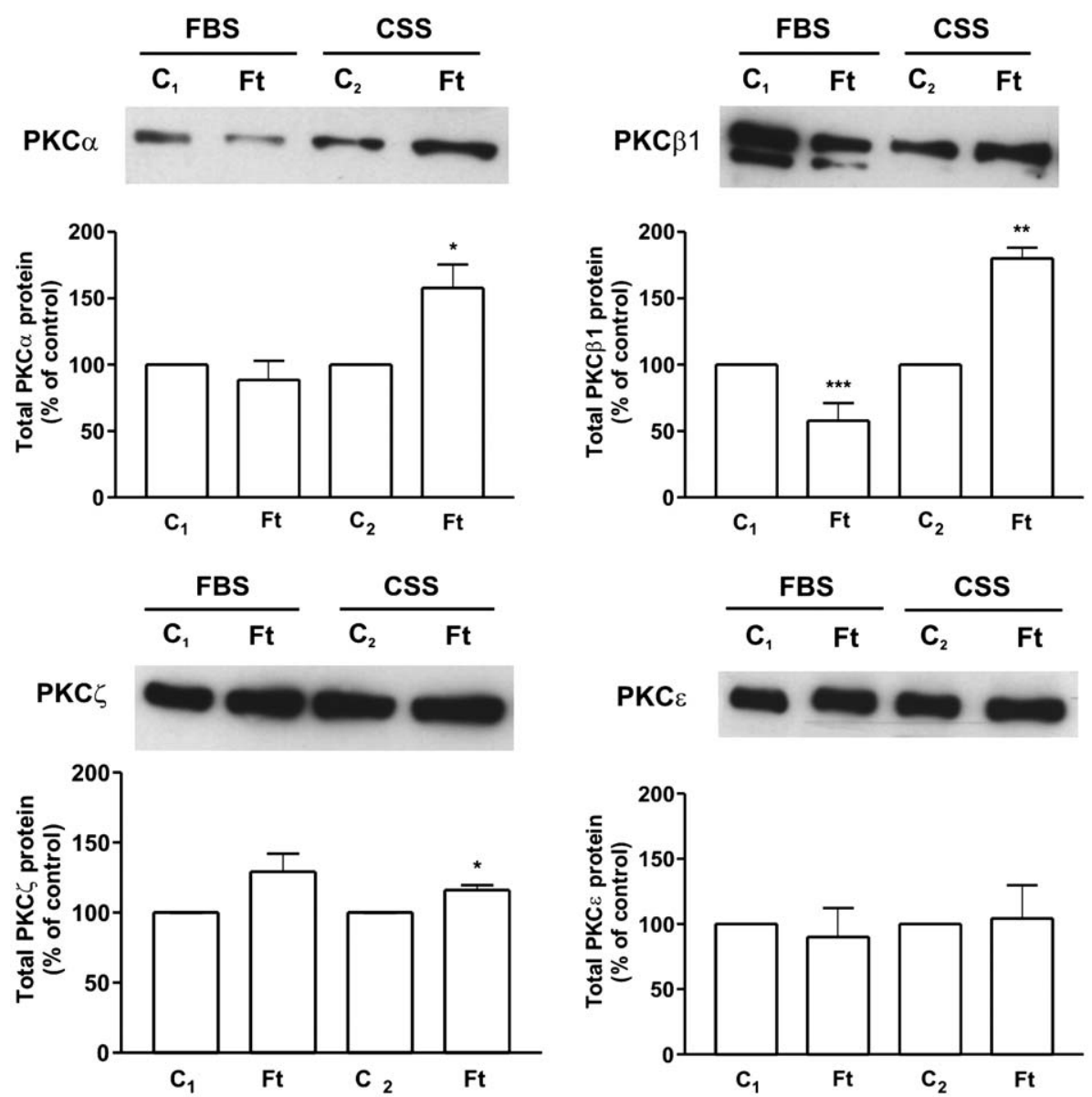

Fig. 2. Regulation of the expression of $\mathrm{PKC}$ isoenzymes in LNCaP human prostate cancer cells by androgen availability. Cells were grown for 3 days in medium supplemented with $10 \%$ FBS or CSS, followed by an additional period of $24 \mathrm{hr}$ in the absence $\left(\mathrm{C}_{1}\right.$ for FBS, and $\mathrm{C}_{2}$ for CSS $)$ and presence $(\mathrm{Ft})$ of $10 \mu \mathrm{M}$ flutamide. Whole cell lysates were separated by SDS-PAGE and immunoblotting was performed with PKC isoenzyme-specific antibodies $(\alpha, \beta 1, \varepsilon, \zeta)$ as indicated. Immunoreactive bands were detected by chemiluminescence (see Methods). The intensities of the bands were quantified by densitometric scanning and normalized by representing them as a percentage of their respective controls $\left(C_{1}, C_{2}\right)$. The bars represent means \pm SEM of four experiments. $* p<0.05, * * p<0.01$.

known target protein for flutamide binding, we examined the possibility that this antiandrogen and/or the culture conditions could induce AR expression. Thus, we carried out RT-PCR analysis of AR from total RNA obtained from PC3 cells cultured in the same conditions used for PKC western blot analyses. As shown in Fig. 4, no PCR products were detected in any of the conditions tested (with FBS or CSS) in PC3 cells whereas, as expected, LNCaP cells were positive for AR expression. This observation leads to the conclusion that flutamide induces the expression of PKC isoforms in PC3 cells by an AR-independent mechanism. 


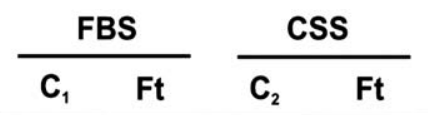

PKC $\alpha$
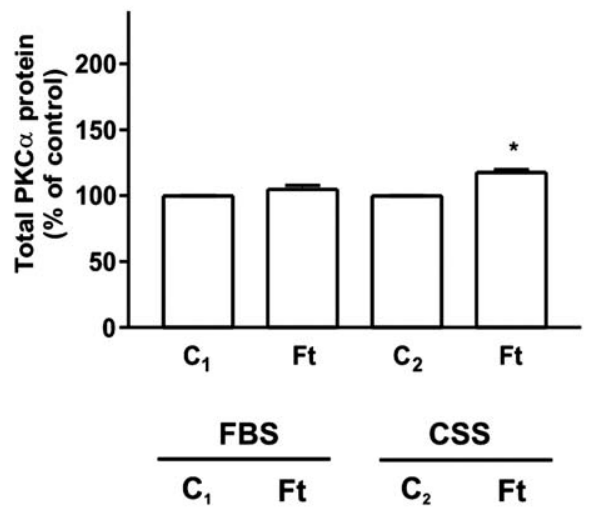

PKC $\zeta$

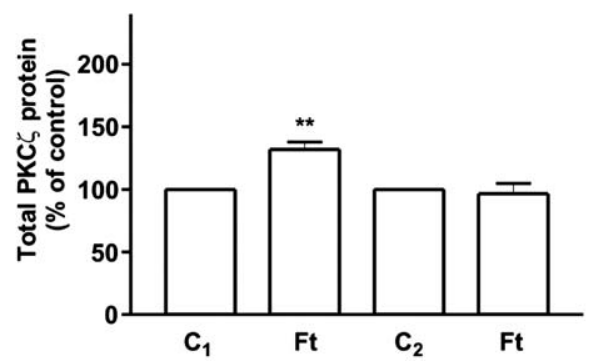

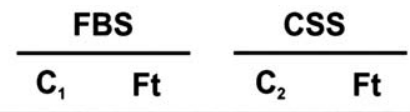

PKC $\beta 1$
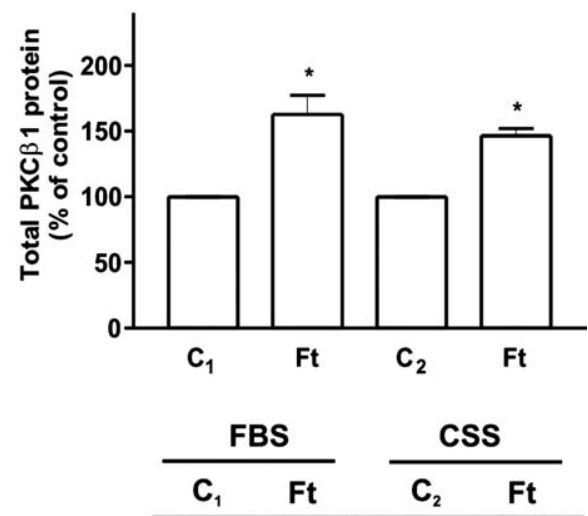

PKC $\varepsilon$

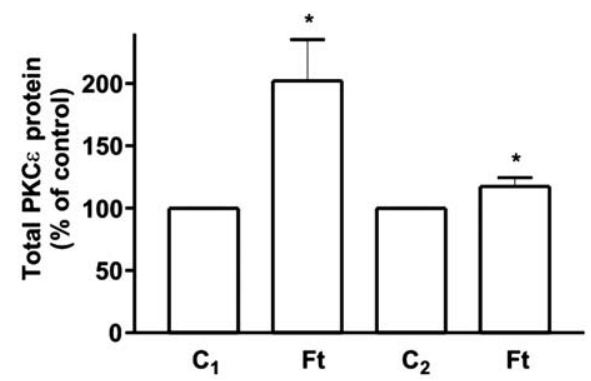

Fig. 3. Regulation of the expression of $\mathrm{PKC}$ isoenzymes in $\mathrm{PC} 3$ human prostate cancer cells by flutamide. See legend for Fig. 2. The bars represent means \pm SEM of four experiments. $* p<0.05$, $* * p<0.01$.

Table 1. Effect of Serum Steroids Availability and Flutamide (Ft) on the Expression of PKC Isoenzymes in LNCaP and PC3 Human Prostate Cancer Cells

\begin{tabular}{|c|c|c|c|c|c|c|c|c|}
\hline & \multicolumn{4}{|c|}{ LNCaP (PKC) } & \multicolumn{4}{|c|}{ PC3 (PKC) } \\
\hline & $\alpha$ & $\beta_{1}$ & $\xi$ & $\varepsilon$ & $\alpha$ & $\beta_{1}$ & $\xi$ & $\varepsilon$ \\
\hline FBS & 100 & 100 & 100 & 100 & 100 & 100 & 100 & 100 \\
\hline $\mathrm{FBS}+\mathrm{Ft}$ & $88 \pm 14$ & $58 \pm 13^{*}$ & $129 \pm 13^{* *}$ & $90 \pm 22$ & $105 \pm 3$ & $163 \pm 15^{*}$ & $132 \pm 6^{*}$ & $202 \pm 33^{* *}$ \\
\hline CSS & $141 \pm 2^{* *}$ & $31 \pm 1$ *** & $130 \pm 12^{* *}$ & $96 \pm 29$ & $119 \pm 4^{*}$ & $119 \pm 19$ & $139 \pm 4^{* * *}$ & $196 \pm 46^{* *}$ \\
\hline $\mathrm{CSS}+\mathrm{Ft}$ & $175 \pm 5^{* * *}$ & $60 \pm 3^{* * *}$ & $150 \pm 9^{* * *}$ & $109 \pm 37$ & $141 \pm 9^{* * *}$ & $147 \pm 6^{* * *}$ & $133 \pm 8^{*}$ & $242 \pm 5^{* * *}$ \\
\hline
\end{tabular}

Results represent the intensity of the immunoreactive band obtained for each PKC isoenzyme. Data are expressed as a percentage of the intensity value from the control $\mathrm{C}_{1}$ (FBS). Data represent the mean \pm SEM of four experiments. ${ }^{*} p<0.01, * * p<0.05, * * * p<0.001$. 


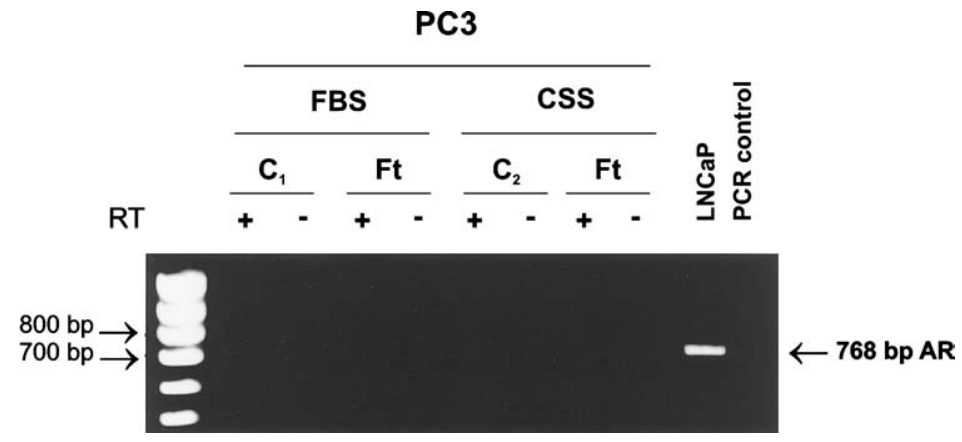

Fig. 4. RT-PCR analysis of the expression of AR mRNA expression in human prostate cancer cells. RT-PCR was performed with total RNA from PC3 cells that had been grown for 3 days in 10\% FBS or CSS followed by $24 \mathrm{hr}$ in the absence or presence of $10 \mu \mathrm{M}$ flutamide as indicated in the corresponding lanes. LNCaP cells were included in the study as AR expression positive control. As negative control, PCR was performed without DNA. A DNA standard lane is shown at the left of the gel, with bands labeled in base pairs. The experiment is representative of three performed.

\section{DISCUSSION}

In the present report, we have analyzed the dependence of the expression of some selected PKC isoenzymes $(\alpha, \beta 1, \varepsilon, \zeta)$ on the availability and/or action of androgens by using androgen-dependent (LNCaP) or independent (PC3) human prostate cancer cells and the antiandrogen flutamide. The effect of flutamide on the expression of these PKC isoforms, at least in PC3 cells, was independent of AR.

By means of immunochemistry, we detected the four PKC isoenzymes studied in both LNCaP and PC3 cells. The differential patterns observed suggest distinct roles for these PKC isoenzymes in the mediation of androgen-related human prostate cancer cell growth. Our observation of the presence of the classical PKC $\alpha$ and $\mathrm{PKC} \beta 1$, the novel $\mathrm{PKC} \varepsilon$ and the atypical $\mathrm{PKC} \zeta$ in both cell lines agrees with previous results in DU145 androgen-insensitive human prostate cancer cells [5] and human prostate adenocarcinoma tissue [7]. The $\alpha, \varepsilon$ and $\zeta$ but not $\beta 1$ isoforms have been previously found in LNCaP cells [25]. Differences related to cell batch or to the antibody used may underpin our ability to detect PKC $\beta 1$ expression in LNCaP cells. Moreover, we have recently observed the same pattern of expression of PKC $\beta 1$ in rat prostate [21], which has been shown to express PKC $\beta 1$ mRNA [26].

PKC plays a fundamental role in the regulation of cell proliferation, differentiation and survival. However, information on the specific role of individual PKC isoenzymes is, to date, limited. Therefore, to establish in a particular cell type agents and situations that regulate PKC expression and/or activity allows association of PKC isoforms with specific cellular functions. PKC activation by phorbol esters induces apoptosis in androgen-sensitive LNCaP cells by activating mainly PKC $\alpha$ and PKC $\delta$ but not in androgen-independent DU145 cells $[8,25]$. This latter finding has been ascribed to a defective apoptotic pathway resulting in growth and survival of cells dependent on the constitutively active $\operatorname{PKC} \alpha[6,27]$. Moreover, inhibition of 
PKC activity appears to be associated with growth inhibition in PC3 cells, in part due to inactivation of $\mathrm{PKC} \alpha$ [28], implying that cellular PKC activity contributes to their faster growth rates. The observation of a similar expression of the atypical $\mathrm{PKC} \zeta$ in the two cell lines studied may be related to a previous finding by Powell et al., who did not observe any effect on tumorigenicity when an aggressive cell subline of the Dunning 3327 rat prostate carcinoma was transfected to stably overexpress this $\mathrm{PKC}$ isoform [29]. By contrast, $\mathrm{PKC} \xi$ is considered to be an oncoprotein since its overexpression confers an oncogenic phenotype to rat fibroblasts [30]. In this regard, increased $\mathrm{PKC} \xi$ expression and attenuation of $\mathrm{PKC} \beta 1$ expression have been associated with progressive neoplasia in the diagnosis of prostate cancer [7], in keeping with present results in PC3 cells that represent the advanced, androgen-insensitive stage of human prostate cancer.

The effect of androgens on rat prostate PKC isoenzymes has previously been reported by Goueli [31]. He observed that castration diminished PKC activity and that this effect is reversed by androgen administration to castrated animals [31]. The present study extends these observations to human prostate cancer cells showing differential regulation of PKC isoforms by both androgen and AR availability. In LNCaP cells, cultured in CSS, we observed a differential regulation of the expression of PCK isoforms, since PKC $\alpha$ and $\mathrm{PKC} \xi$ were up-regulated, whereas no change was observed $\mathrm{PKC} \varepsilon$. In addition, $\mathrm{PKC} \beta 1$ levels were significantly diminished compared to FBS conditions. This pattern of expression of $\mathrm{PKC}$ isoforms was slightly different in PC3 cells cultured in the same conditions as LNCaP cells. In PC3 cells, we observed up-regulation of $\mathrm{PKC} \varepsilon$ (in addition to $\mathrm{PKC} \alpha$ and $\mathrm{PKC} \xi$ ) and no effect on PKC $\beta 1$ expression. Taken together, these results suggest: (1) that androgens and other steroids present in serum down-regulate the expression of $\mathrm{PKC} \alpha$ and $\mathrm{PKC} \xi$ isoenzymes since these $\mathrm{PKC}$ isoforms exhibit a similar regulation pattern in both LNCaP and PC3 cells; (2) that androgens up-regulate PKC $\beta 1$ expression, as evidenced by the down-regulation observed in CSS-LNCaP cells and the absence of any effect in CSS-PC3 cells; (3) that androgens do not regulate the expression of $\mathrm{PKC} \varepsilon$, since no effect was observed in LNCaP cells and the up-regulation observed in PC3 cells was independent on AR.

Flutamide potentiated the expression of the four PKC isoenzymes studied in both LNCaP and PC3 cells incubated in the absence of androgens (with the exception of $\mathrm{PKC} \varepsilon$ in $\mathrm{LNCaP}$ and $\mathrm{PKC} \zeta$ in $\mathrm{PC} 3$ cells) whereas the results were more heterogeneous in the presence of androgens. The nonsteroidal antiandrogen flutamide competes with dihydrotestosterone for binding to the AR. Therefore, it is widely used in combination with androgen suppressive procedures and even as monotherapy in advanced prostate cancer [9]. This drug exerts an inhibitory effect on prostate cell proliferation by blocking androgen action, as well as on bone formation and spermatogenesis [32-34]. Interestingly, flutamide has been reported to behave as an AR agonist in human prostate cancer tissue with an AR gene mutation and in human LNCaP cells [14-16, 18]. The agonist-like response was observed at the level of prostate specific antigen (PSA) expression or cell growth and has important implications for the treatment of prostate cancer. The present results extend these observations by implicating the expression of PKC isoenzymes that modulate the mechanisms of cell proliferation, apoptosis and neoplastic transformation [1, 2]. Whereas PC3 cells are androgen-insensitive and have lost AR expression, LNCaP 
cells overexpress a mutated AR and represent cells that have adapted the AR pathway to be able to grow and survive in patients treated with hormone therapy [35, 36]. It has been reported that flutamide can behave as an agonist on AR phosphorylation (i.e., activation), resulting in increased PSA expression in LNCaP cells [18]. This feature is closely related to our results with the same cell line cultured with CSS (to deprive the cells of androgens, other steroids and, in all likelihood, some growth factors) since flutamide augmented the expression of $\mathrm{PKC} \beta 1$ isoenzyme in contrast as CSS did. However, when LNCaP cells were cultured in a medium with full serum, flutamide showed diverse effects on the expression of $\mathrm{PKC}$ isoenzymes, which may be due to the difficulty in blocking all available androgens. This point is relevant since androgen ablation in patients with prostate cancer does not result in total abolition of androgen levels $[9,10]$.

Our observation that flutamide stimulates the expression of $\mathrm{PKC}$ isoenzymes in almost all the conditions tested (either in the presence or absence of androgens) in PC3 cells was quite surprising. In addition, we did not find any expression of AR by RT-PCR. The mechanism of action of flutamide underlying the regulation of PKC expression in PC3 cells remains unknown but is of interest since many subpopulations of cells have lost AR expression altogether in the late-stage of androgenindependent prostate cancer [36]. In this context, because biological responses require the integration of diverse signals, a full understanding of the consequences of flutamide effects on the expression and activity of PKC isoenzymes may be valuable.

In summary, the present report demonstrates that the antiandrogen flutamide up-regulates the expression of various PKC isoenzymes in androgen-deprived LNCaP cells. Whether such an effect is exerted via the mutated AR molecule of these cells and/or other target molecules remains unclear. These effects are also detected in PC3 cells, which lack AR expression, so that they must be conceivably reached, at least in this case, through an androgen-independent mechanism. The results reinforce and extend previous observations on the changing agonistic or antagonistic activity of drugs used in the treatment of prostate cancer, depending on the extent of the mutation and the phosphorylation/dephosphorylation status of the AR [12-18], and describe for the first time an effect of flutamide that is independent of the AR.

\section{ACKNOWLEDGMENTS}

This work was supported by grants from the Ministerio de Educación y Cultura (PM 97-0069), Ministerio de Ciencia y tecnología (SAF2001-1025), ScheringPlough, S.A., Alonga-Grupo Synthelabo and Fundación para la Investigación en Urología. We thank Prof. L. Puebla for English assistance.

\section{REFERENCES}

1. Kanashiro, C. A., and Khalil, R. A. (1998) Clin. Exp. Pharmacol. Physiol. 25: 974-985.

2. Spitaler, M., Wiesenhofer, B., Biedermann, V., Seppi, T., Zimmermann, J., Grunicke, H., et al. (1999) Anticancer Res. 19: 3969-3976.

3. Mellor, H., and Parker, P. J. (1998) Biochem. J. 332: 281-292.

4. Martelli, A. M., Sang, N., Borgatti, P., Capitani, S., and Neri, L. M. (1996) J. Cell Biochem. 74: 499-521.

5. Rusnak, J., and Lazo, J. S. (1996) Exp. Cell. Res. 224: 189-199. 
6. O’Brian, C. A. (1998) Oncol. Rep. 5: 305-309.

7. Cornford, P., Evans, J., Dodson, A., Parsons, K., Woolfenden, A., Neoptolemos, J., et al. (1999) Am. J. Pathol. 154: 137-144.

8. Fujii, T., García-Bermejo, M. L., Bernabó, J. L., Caamaño, J., Ohba, M., Kuroki, T., et al. (2000) J. Biol. Chem. 275: 7574-7582.

9. Boccardo, F. (2000) Oncol. Hematol. 35: 121-132.

10. Buttyan, R., Shabsigh, A., Perlman, H., and Colombel, M. (1999) Trends Endocrinol. Metab. 10: 47-54.

11. Reid, P., Kantoff, P., and Oh, W. (1999) Invest. New Drug 17: 271-284.

12. Sadar, M. D., Hussain, M., and Bruchovsky, N. (1999) Endocr. Relat. Cancer 6: 487-502.

13. Brinkman, A. O. (2001) Mol. Cell. Endocrinol. 179: 105-109.

14. Schoenberg, M. P., Hakimi, J. M., Wang, S., Bova, S., Epstein, J. I., Fischbeck, K. H. et al. (1994) Biochem. Biophys. Res. Commun. 198: 74-80.

15. Fenton, M. A., Shuster, T. D., Fertig, A. M., Taplin, M. E., Kolvenbag, G., Bubley, G. J. et al. (1997) Clin. Cancer Res. 3: 1383-1388.

16. Wilding, G., Chen, M., and Gelmann, E. P. (1989) Prostate 14: 103-115.

17. Veldscholte, J., Ris-Stalpers, C., Kuiper, G. G., Jenster, G., Berrevoets, C., Claassen, E. et al. (1990) Biochem. Biophys. Res. Commun. 173: 534-540.

18. Wang, L. G., Liu, X. M., Kreis, W., and Budman, D. R. (1999) Biochem. Biophys. Res. Commun. 259: 21-28.

19. Montalvo, L., Carmena, M. J., Solano, R. M., Clemente, C., Román, I. D., Sánchez-Chapado, M., et al. (2000) Cell. Signal. 12: 311-316.

20. Carmena, M. J., García-Paramio, P., Solano, R. M., and Prieto, J. C. (1995) Prostate 27: 204-211.

21. Montalvo, L., Sánchez-Chapado, M., Prieto, J. C., and Carmena, M. J. (2002) Life Sci. 71: 2257-2266.

22. Lee, M. J., Van Brocklyn, J. R., Thangada, S., H and, A. R., Menzeleev, R., Spiegel, S., and Hla, T. (1998) Science 279: 1552-1555.

23. Bradford, M. A. (1976) Anal. Biochem. 78: 248-254.

24. Koivisto, P., Kononen, J., Palmberg, C., Tammela, T., Hyytinen, E., Isola, J. et al. (1997) Cancer Res. 57: 314-319.

25. Powell, C. T., Brittis, N. J., Stec, D., Hug, H., Heston, W. D., and Fair, W. R. (1996) Cell. Growth Differ. 7: 419-428.

26. Powell, C. T., Fair, W. R., and Heston, W. D. (1994) Cell. Growth Differ. 5: 143-149.

27. Zhao, X., Gschwend, J., Powell, T., Foster, R. G., Day, K. C., and Day, M. L. (1997) J. Biol. Chem. 272: 22751-22757.

28. Lamm, M. L., Long, D. D., Goodwin, S. M., and Lee, C. (1997) Endocrinology 138: 4657-4664.

29. Powell, C. T., Gschwend, J. E., Fair, W. R., Brittis, N. J., Stec, D., and Huryk, R. (1996) Cancer Res. 56: $4137-4141$.

30. Cacace, A. M., Guadagno, S. N., Krauss, R. S., Fabbro, D., and Weinstein, I. B. (1993) Oncogene 8: 2095-2104.

31. Goueli, S. A. (1990) FEBS Lett. 264: 53-55.

32. Labrie, F. (1993) Cancer 72: 3816-3827.

33. Gallagher, A. C., Chambers, T. J., and Tobias, J. H. (1996) Am. J. Physiol. 270:E407-E412.

34. Kangasniemi, M., Dodge, K., Pemberton, E., Huhtaniemi, I., and Meistrich, M. L: (1996) Endocrinology 137: 949-955.

35. Tilley, W. D., Wilson, C. M., Marcelli, M., and McPhaul, M. J. (1990) Cancer Res. 50: 5382-5386.

36. Jenster, G. (1999) Sem. Oncol. 26: 407-421. 